\title{
Implementasi Sistem Layanan Pengaduan Masyarakat Kecamatan Medan Amplas Berbasis Website
}

\author{
Yudha Sansena \\ Universitas Islam Negeri Sumatera Utara \\ yudha.sansena@uinsu.ac.id
}

\begin{abstract}
ABSTRAK. Semakin majunya penggunaan teknologi informasi, sudah semestinya setiap instansi pemerintah berusaha dalam meningkatkan kualitas pelayanannya. Salah satunya dalam pelayanan pengaduan masyarakat adalah bentuk partisipasi pemerintah untuk membangun dan mengawasi kinerja instansi pemerintah dalam melayani masyarakat. Pada penelitian ini mengambil studi kasus di Kecamatan Medan Amplas, Kota Medan dimana masyarakat masih sulit menyampaikan keluhan yang ada di lingkungan mereka terhadap pemerintah setempat. Sehingga orang yang tidak mengerti menyebarkan keluhannya di tempat yang salah. Oleh sebab itu, perlu adanya sistem layanan pengaduan masyarakat berbasis website sebagai ruang aspirasi yang dapat diakses dengan mudah. Perancangan website menggunakan metode Waterfall, dibangun dengan bahasa skrip Sublime Text 3, PHP serta Xampp 7.4.6 sebagai database-nya, dan pengujian sistem menggunakan blackbox testing sehingga membuat sistem informasi berbasis website sebagai sarana untuk memenuhi aspirasi publik yang relevan dan tersedia di Internet.
\end{abstract}

Kata Kunci: website;Pengaduan Masyarakat;Kecamatan Medan Amplas

ABSTRACT. The more advanced the use of information technology, every government agency should strive to improve the quality of its services. One of them in the service of community complaints is a form of government participation to build and supervise the performance of government agencies in serving the community. In this study took a case study in Medan Amplas Subdistrict, Medan City where people still find it difficult to convey complaints in their neighborhood against the local government. So that people who do not understand spread their complaints in the wrong place. Therefore, there needs to be a website-based community complaint service system as an aspirational space that can be accessed easily. Website designing uses the Waterfallmethod, built with the sublime text 3 script language, PHP and Xampp 7.4.6 as its database, and testing systems using blackbox testing thus creating a website-based information system as a means to meet relevant public aspirations and available on the Internet.

Keywords: website; Community Complaints; Medan Amplas Subdistrict

\section{PENDAhuluan}

Seiring kemajuan Perkembangan ilmu teknologi dan informasi yang begitu pesat menyebabkan perubahan kinerja dalam menyelesaikan masalah, baik dalam masyarakat maupun instansi pemerintahan. Perkembangan teknologi yang dapat dirasakan saat ini adalah teknologi internet.

Salah satu pemanfaatan teknologi internet ialah untuk mengakses informasi yang tersebar di dunia maya. Masyarakat dengan mudah dan tepat waktu mengakses informasi yang berkembang di Internet. Mulai dari perkembangan informasi masyarakat umum hingga perkembangan orang-orang penting di dunia. Informasi, memudahkan masyarakat untuk mencari ilmu dari lingkungan hingga ke belahan dunia lainnya, masyarakat juga dengan mudah menangkap informasi di lingkungan pemerintahan. situasi ini memicu masyarakat semakin rensponsif terhadap pemerintah. Penilaian publik juga mengakomodasi pemerintah mengevaluasi program kerja yang mereka laksanakan. (Rohmatun et al., 2017).

Informasi sangat penting bagi setiap individu atau lembaga pemerintah untuk membuat keputusan. Mengingat pesatnya peredaran informasi di dunia, setiap institusi pemerintah diharapkan mampu dengan cepat dan akurat menyampaikan semua informasi yang diterima dan dimilikinya, serta menemukan dan memberikan solusi dengan masalah yang muncul di tengah-tengah masyarakat. Untuk mewujudkan hal tersebut, peningkatan layanan publik menjadi salah satu bagian dalam penerimaan informasi bagi pemerintah pemerintah, salah satu layanan publik yang dapat di terapkan dan mendukung kinerja pemerintah adalah dengan adanya pengaduan masyarakat.

Peningkatan pelayanan umum mewujudkan salah satu bentuk kontribusi pemerintah kepada masyarakat. Apabila kita melihat ke belakang, situasi pelayanan publik tetap memprihatinkan. Berperan dalam membangun lingkungan dan mengawasi kinerja institusi pemerintah, informasi dan suara publik bisa digunakan sebagai bahan rujukkan untuk mengevaluasi kebijakan dan peraturan yang telah di tata atau 
diterapkan serta untuk mengungkap permasalahan di masyarakat secara efektif, cepat dan efisien. (Hardiansah et al., 2017).

Pemerintah memegang tanggung jawab untuk menangani aspirasi yang disampaikan oleh publik, menanggapi setiap keluhan yang disampaikan dan memberikan respon yang solutif atas permasalahan yang disampaikan oleh masyarakat. Pemerintah diharapkan mempunyai fasilitas pelayanan yang mampu dijangkau melalui Internet sehingga masyarakat dapat dengan mudah menyalurkan usahanya tanpa harus ke kantor, meringankan masyarakat dari masalah pembangunan kota, melaporkan atau mengadukan masalah pemerintah; dan hal-hal yang berkaitan dengan fasilitas umum yang tidak memadai. Karena masalah-masalah tersebut dapat menjadi penghambat kemajuan suatu pemerintahan(Rohmatun et al., 2017).

Permasalahan yang muncul bisa diselesaikan dengan pemanfaatan teknologi, salah satunya ialah website. Dengan situs web kita dapat dengan mudah mengakses semua informasi dari perangkat pencarian apa pun. Apabila terjadi masalah di lingkungan masyarakat, seperti kerusakan fasilitas umum dan gangguan di masyarakat, contohnya jalan rusak, pemungutan liar, kriminalitas, sampah, dan lain sebagainya. Dengan teknologi ini, masyarakat kini dapat mengeluh, berkomentar, dan menghubungi pihak Kelurahan untuk menyelesaikan masalah secara efektif dan efisien.

Kecamatan Medan Amplas adalah salah satu dari 21 kecamatan di kota Medan yang terdiri dari 7 kelurahan didalamnya. Medan Amplas juga merupakan hub sarana transportasi darat di selatan, membuat kecamatan ini rentan terhadap kerusakan fasilitas umum dan tindak kriminal. Hal ini meresahkan masyarakat. Oleh karena itu, pengaduan masyarakat diperlukan untuk membantu meningkatkan fasilitas umum dan menghilangkan gangguan masyarakat terkait kejahatan. Namun, minimnya pengaduan disebabkan sistem birokrasi yang mengharuskan pelapor mendatangi kelurahan terkait. Layanan pengaduan masyarakat berbasis web diperlukan untuk menerobos sistem birokrasi yang tidak relevan dan membuat proses pengaduan menjadi lebih efisien.

Penelitian terkait menurut Cahya Firmansyah dan Cucu Tohir, dengan judul "Sistem Layanan Pengaduan Masyarakat Lingkup Desa Gunungtanjung Berbasis Web Dan Sms Gateway Dengan Metode Antrian Fifo" didapatkan hasil bahwa Sistem pelayanan pengaduan masyarakat dapat memberikan respon yang lebih cepat dan efektif dari pengguna dan menghubungkan masyarakat dengan pemerintah. Pemkot dapat berhubungan dengan pengaduan atau permasalahan dalam pelayanan publik melalui pesan singkat atau SMS, dan pegawai pengelola pengaduan kelurahan mendapatkan kenyamanan dalam pengolahan data pengaduan dan dalam penyusunan laporan data pengaduan sampai dengan periode waktu tertentu(Firmansyah \& S, 2018).

Penelitian serupa yang dilakukan oleh Siti Widhareto Mursalim dalam jurnalnya yang bertajuk “Analisis Manajemen Pengaduan Sistem Layanan Aspirasi Pengaduan Online Rakyat (Lapor) Di Kota Bandung", menghasilkan Secara keseluruhan bahwa keberadaan sistem layanan pengaduan bertujuan untuk membantu masyarakat sebagai wadah dalam mengeluarkan aspirasi atau pengaduan terhadap kinerja pemerintah guna mempermudah penyampaian pengaduan publik atau aspirasi yang berkaitan dengan kinerja pemerintah. Laporan ini dapat diakses, sederhana, cepat, adil, rahasia, catatan dan pemulihan (Mursalim, 2018).

Serupa dengan penelitian sebelumnya, menurut Hardiansyah, dkk, mengatakan dalam jurnalnya yang berjudul "Rancangan Aplikasi Layanan Pengaduan Masyarakat Dengan MetodeExtreme Programming", mendapatkan hasil bahwa Dengan adanya sistem layanan aspirasi ini dapat menhubungkan kesenjangan antara masyarakat dengan pemerintah untuk menyampaikan pengaduan sehingga dapat menindaklanjuti pengaduan dan aspirasi secara langsung. (Hardiansah et al., 2017).

\section{II.METODE}

Metode penelitian yang digunakan untuk rancangan aplikasi bebasis website ini adalah metode Waterfall Model. Waterfall Model contoh proses desain sistem yang fase utamanya secara langsung merepresentasikan dasar perencanaan sistem, seperti analisis dan definisi kebutuhan, desain sistem, perangkat lunak, implementasi, dan pengujian sistem. (Mahdias et al., 2019) yang dapat dilihat pada Gambar 1. 


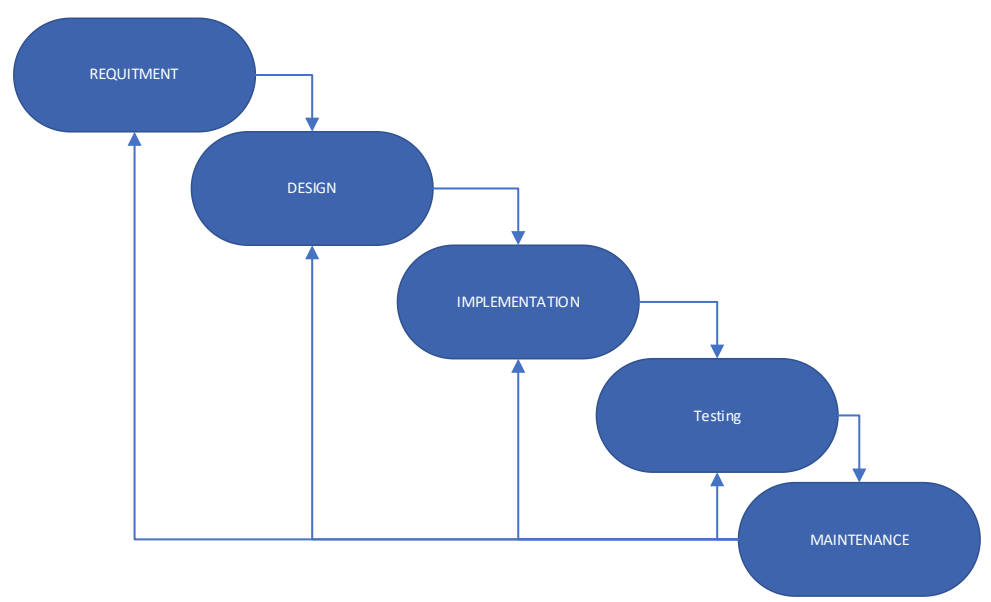

Gambar 1. Metode waterfall

Dengan metode Waterfall Model menggambarkan pendekatan yang sistematis sehingga menjadi serangkaian penelitian yang dilakukan, diantaranya:

\section{Analisis kebutuhan}

Pada tahap analisis, peneliti mengkaji persoalan mendasar dan kemungkinan yang ada di lapangan dalam perancangan aplikasi layanan pengaduan masyarakat berbasis website dengan melakukan studi literatur dan dengar pendapat dengan Lurah serta Kepala lingkungan setempat.

\section{Design}

Pada tahap perencanaan penulis membuat arsitektur perencanaan layanan pengaduan masyarakat seperti pada Gambar 2.

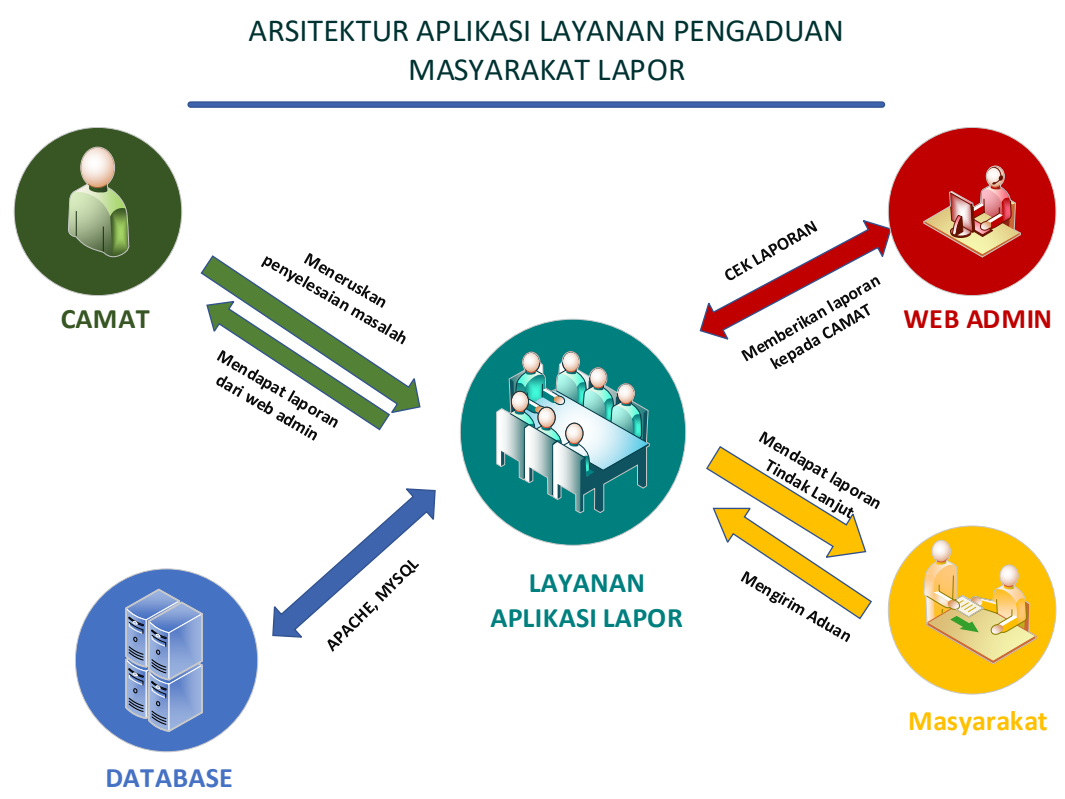

Gambar 2. Arsitektur Aplikasi Layanan Pengaduan Masyrakat Kecamatan Medan Amplas

Arsitektur ini sebagai bentuk konsep awal untuk membangun sistem layanan pengaduan masyarakat yang akan di implementasikan dalam website. Penulis membuat rancangan tampilan antarmuka pada website seperti tampilan pada Gambar 3. 


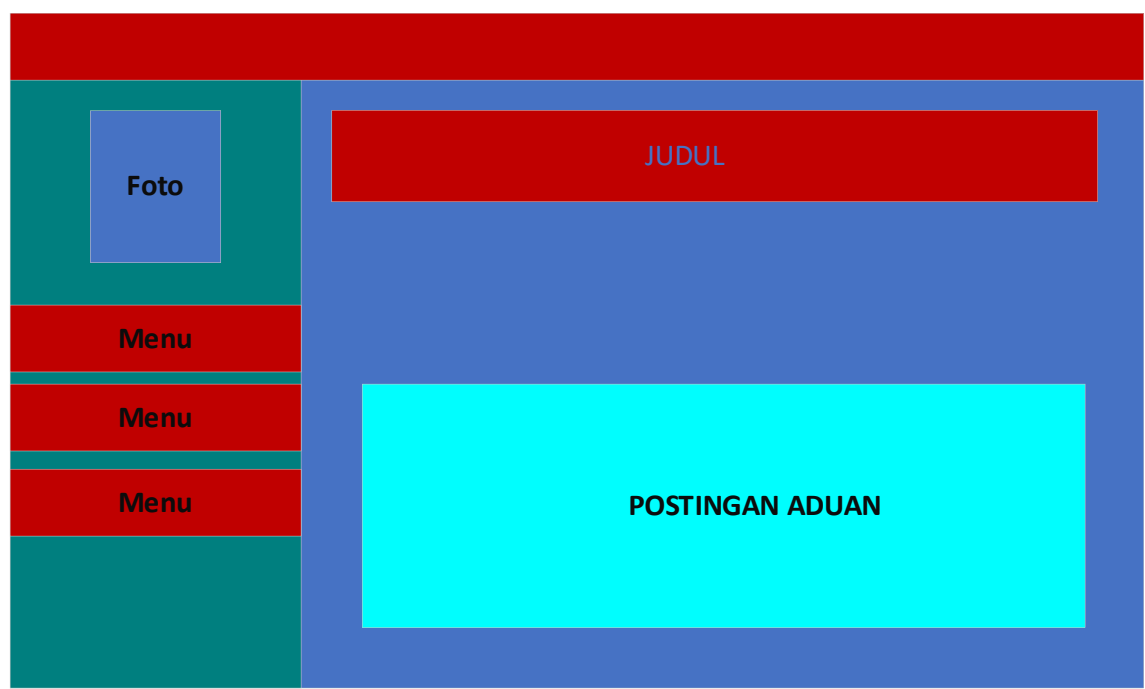

Gambar 3. Antarmuka halaman utama website

Pada tahap design diperlukan alur berjalannya sebuah program atau disebut flowchart. Flowchart bertujuan menjelaskan tentang alur sistem nantinya. Flowchart terlihat seperti pada Gambar 4.

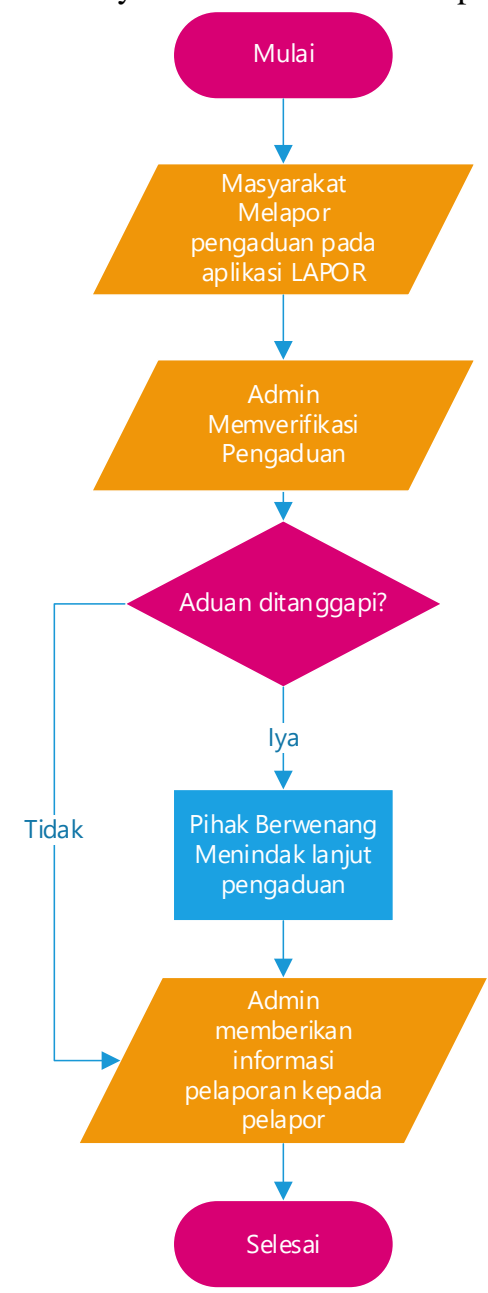

Gambar 4. Flowchart aplikasi layanan pengaduan masyrakat 
Selanjutnya ialah mendesain diagram aktivitas untuk menggambarkan ilustrasi kegiatan dalam pengaplikasian pengguna website. Dibawah ini terdapat Gambar 5 yang menampilkan alur kegiatan.

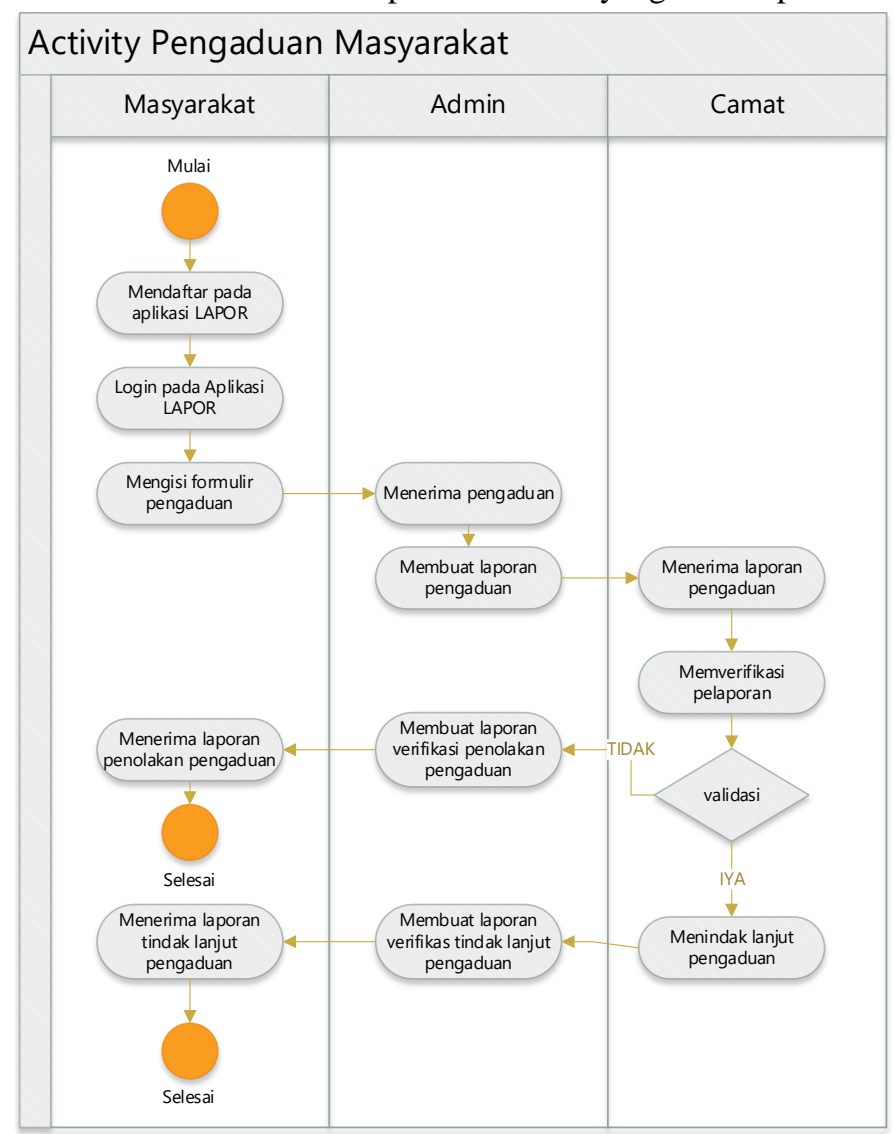

Gambar 5. Diagram Activity Pengaduan Masyarakat

Berikutnya Menggambarkan activity diagram awal mula login pada halaman website sebelum masuk ke halaman utama, seperti pada Gambar 6.

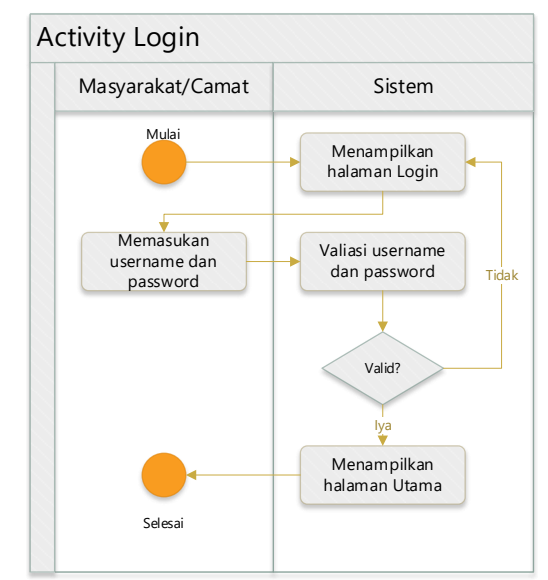

Gambar 6. Activity diagram login

Berikutnya Menggambarkan activity diagram proses pelapor melakukan pengaduan pada halaman website untuk memvalidasi data aduannya, seperti pada Gambar 7. 


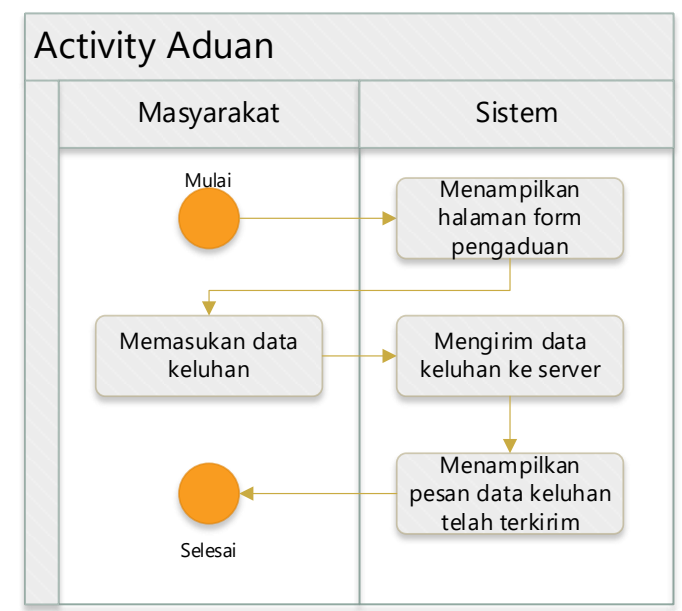

Gambar 7. Activity diagram aduan

Berikutnya Menggambarkan activity diagram proses Camat melakukan verifikasi pada halaman website untuk memvalidasi data aduan pelapor, seperti pada Gambar 8.

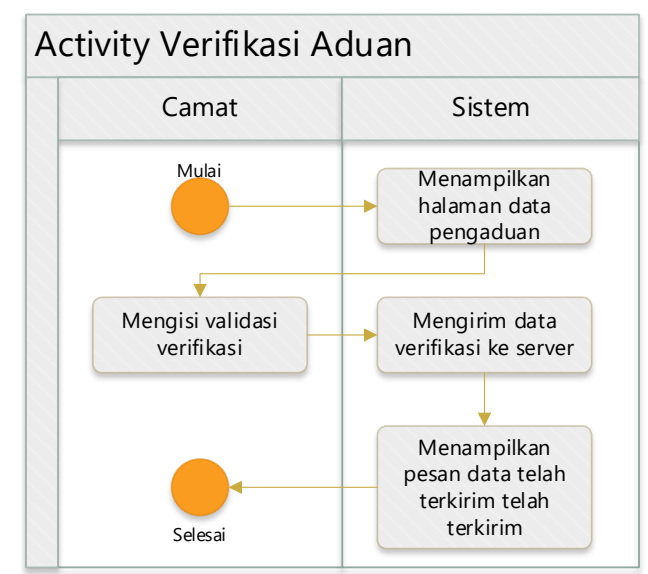

Gambar 8. Activity diagram verifikasi aduan

Langkah selanjutnya adalah membuat kode dan membangun sistem informasi layanan pengaduan, kemudian menguji sistem dengan uji black box untuk melihat apakah sistem yang dibuat layak atau tidak.

\section{Implementasi}

Pada tahap ini telah dilakukan implementasi aplikasi website yang digunakan untuk menjembatani antara pengguna dan sistem dalam melakukan pengaduan di Kecamatan Medan Amplas Kota Medan. Pada tahap implementasi ini penulis melakukan coding menggunakan PHP dengan dukungan platform Sublime Text 3 dan database yang digunakan adalah XAMPP versi 7.4.6 serta program lain yang mendukung pembuatan aplikasi web.

\section{Lokasi Penelitian}

Penelitian ini dikukan pada Kecamatan Medan Amplas, Kota Medan. Subjek dari penelitian ini adalah masyarakat dan pejabat setempat. 


\section{Teknik Pengumpulan Data}

Teknik pengumpulan data untuk menggali informasi yang diperlukan untuk mengembangkan sistem pelayanan pengaduan masyarakat. Metode yang dilakukan adalah observasi dan wawancara. Obsevasi digunakan untuk mendapatkan informasi langsung respon dari pengguna perihal penggunaan sistem layanan pengaduan masyarakat. Wawancara digunakana untuk memperoleh tanggapan mengenai masukan, saran dan kritikan guna tujuan pengembangan sistem layanan pengaduan masyarakat.

\section{Teknik Analisis Data}

Teknik analisis data yang digunakan dalam penelitian ini yaitu penelitian deskriptif kuantitatif (Sari \& S, 2020). Penelitian deskriptif ini bermaksud untuk mengetahui dan mengkaji dampak sistem yang akan dibentuk dalam menanggapi pengaduan masyarakat di Kecamatan Medan Amplas Kota Medan.

\section{HASIL DAN PEMBAHASAN}

Hasil investigasi pelaksanaan ini tersedia dalam bentuk website layanan pengaduan masyarakat dalam rangka memfasilitasi penyediaan layanan pengaduan masyarakat. Hasil visualisasi dalam penelitian ini disajikan di bawah ini:

\section{Halaman Login}

Pada tampilan pertama membuka situs ialah berupa tampilan login untuk dapat akses masuk ke halaman utama. Halaman login berisi logo website, formulir login ke halaman utama, dan terdapat link registrasi bagi pengguna untuk mendapatkan akun yang terlihat seperti pada Gambar 9.

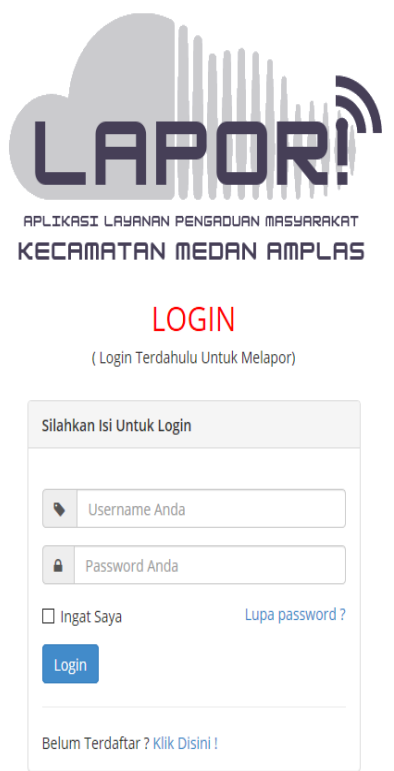

Gambar 9. Tampilan Login 


\section{Halaman Daftar}

Pada tampilan daftar terdapat formulir pengisian data diri pengguna baru yang nantinya memberi akun untuk akses login pada halaman utama, terlihat seperti Gambar 10.

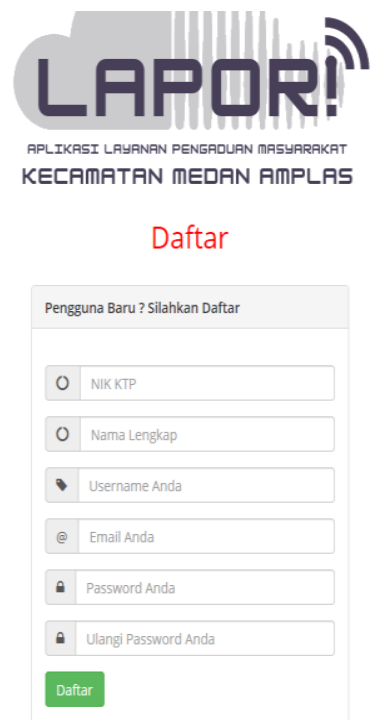

Gambar 10. Tampilan halaman daftar

\section{Halaman Utama}

Pada Tampilan utama ini menampilkan beberapa menu seperti menu Pengaduan, akun, Beranda, Tentang, Kontak dan Laporan, terlihat pada Gambar 11.

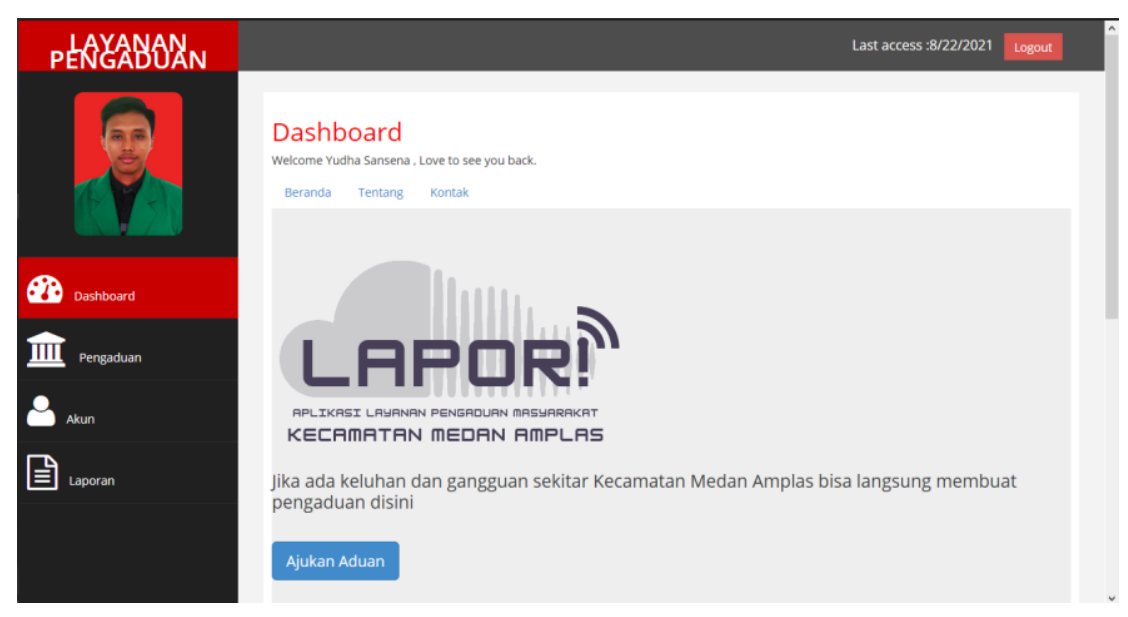

Gambar 11. Tampilan Halaman Utama 


\section{Halaman Pengajuan Aduan}

Pada halaman pengajuan aduan menampilkan beberapa formulir pengajuan seperti data pelapor, lokasi kejadian perkara, dan kronologi kejadian, seperti terlihat pada Gambar 12.

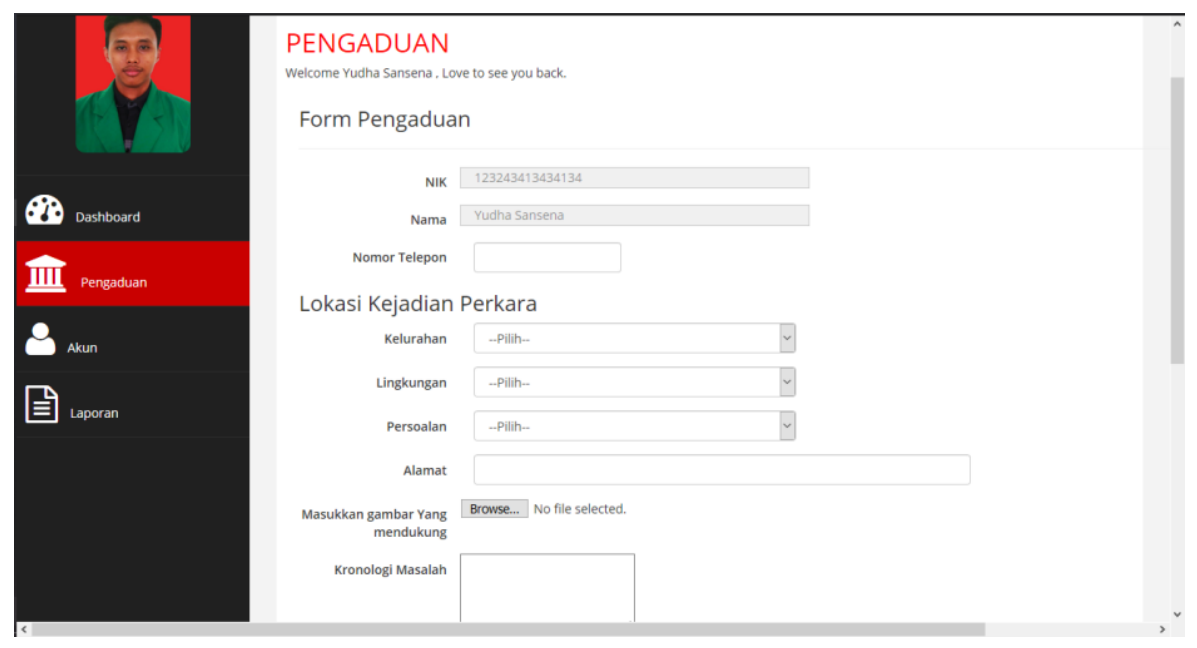

Gambar 12. Tampilan Formulir Pengajuan Aduan

\section{Halaman Verifikasi}

Halaman Verifikasi hanya tersedia pada akun Camat, didalamnya berisi data-data aduan dan detail pengaduan, visual yang terlihat pada Gambar 13.

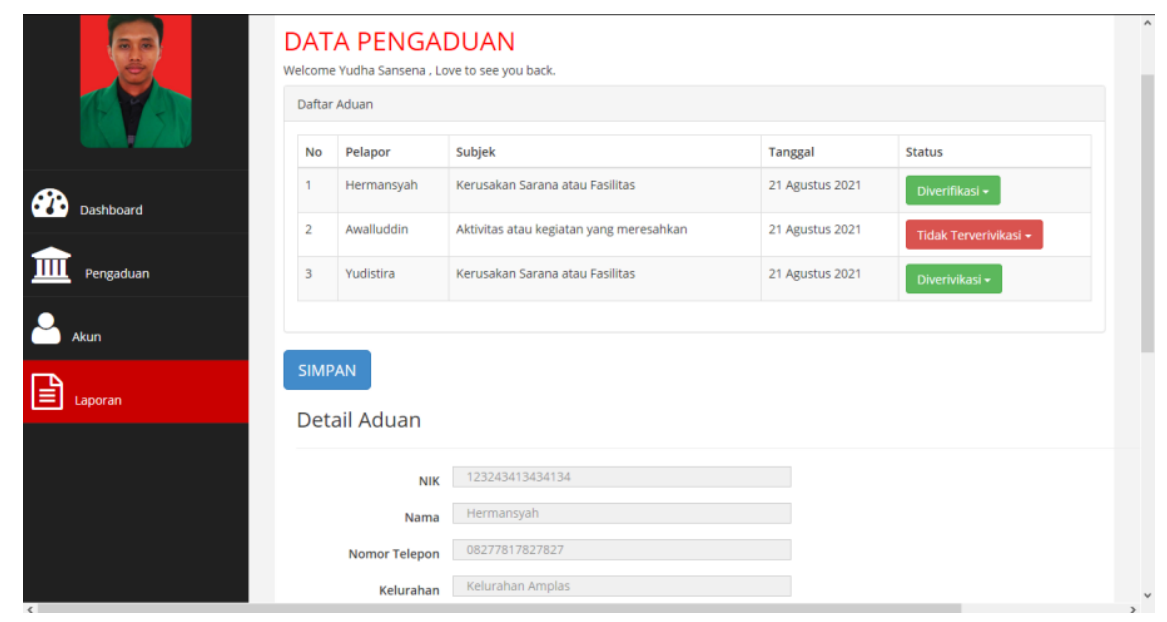

Gambar 13.Tampilan Laporan Aduan pada Akun Camat

Pada tampilan detail aduan terdapat rincian data yang dilaporkan seperti terlihat pada Gambar 14. Tampilan ini berfungsi untuk meninjau data pengaduan dari pelapor agar mengetahui ditindak lanjut yang akan dilakukan 


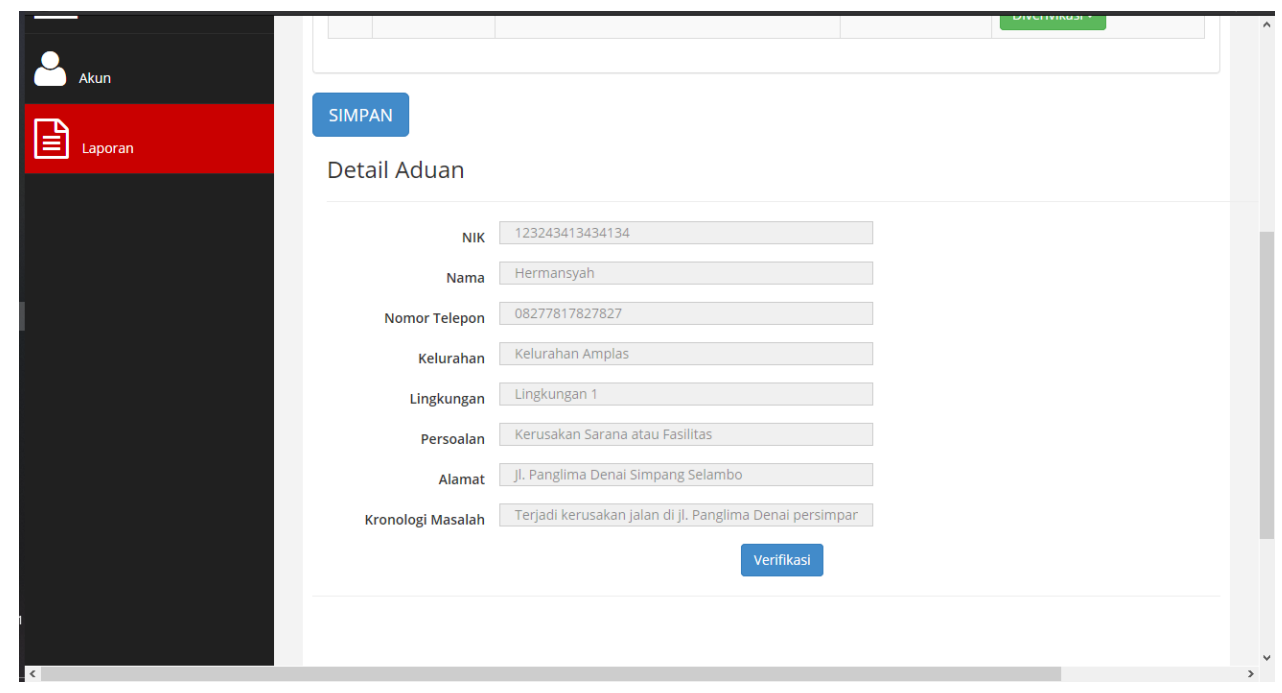

Gambar 14. Tampilan Detail Aduan

\section{Pengujian Sistem}

Pengujian black box adalah bagian terpenting dalam mengembangkan aplikasi, pengujian yang menggunakan pengujian black box berfokus pada spesifikasi fungsi sistem yang dibangun, mendefinisikan kondisi input oleh pengguna, dan menjalankan penguji spesifikasi fungsional program aplikasi. Hasil uji black box ditunjukkan pada Tabel 1.

Tabel 1. Pengujian sistem black box testing

\begin{tabular}{|c|c|c|c|c|}
\hline No & Kasus/diuji & Skenario Uji & Hasil Yang di Harapkan & Hasil Pengujian \\
\hline 1. & Tampilan Awal & $\begin{array}{l}\text { Memilih Launcher } \\
\text { Icon Teks Layanan } \\
\text { Pengaduan }\end{array}$ & $\begin{array}{c}\text { Ketika icon } \\
\text { diklik/disentuh maka } \\
\text { aplikasi berjalan dan } \\
\text { masuk ke tampilan utama }\end{array}$ & Berhasil \\
\hline 2. & Menu Pengaduan & $\begin{array}{l}\text { Memilih Menu } \\
\text { Pengaduan }\end{array}$ & $\begin{array}{c}\text { Ketika Menu } \\
\text { diklik/disentuh maka } \\
\text { aplikasi akan berjalan dan } \\
\text { masu ke tampilan } \\
\text { formulir pengaduan }\end{array}$ & Berhasil \\
\hline \multirow[t]{2}{*}{3.} & Menu Laporan & $\begin{array}{l}\text { Memilih Menu } \\
\text { Laporan pada User }\end{array}$ & $\begin{array}{c}\text { Ketika Menu } \\
\text { diklik/disentuh maka } \\
\text { aplikasi akan berjalan dan } \\
\text { masuk ke tampilan daftar } \\
\text { aduan(User) }\end{array}$ & Berhasil \\
\hline & & $\begin{array}{l}\text { Memilih Menu } \\
\text { Laporan pada } \\
\text { Admin/Camat }\end{array}$ & $\begin{array}{c}\text { Ketika Menu } \\
\text { diklik/disentuh maka } \\
\text { aplikasi akan berjalan dan } \\
\text { masuk ke tampilan daftar } \\
\text { aduan dan data } \\
\text { Verikfikasi } \\
\text { aduan(Admin/Camat) }\end{array}$ & Berhasil \\
\hline 4 & Menu Akun & Memilih Menu Akun & $\begin{array}{c}\text { Ketika Menu } \\
\text { diklik/disentuh maka } \\
\text { aplikasi akan berjalan } \\
\text { masuk ke tampilan akun }\end{array}$ & Berhasil \\
\hline
\end{tabular}




\begin{tabular}{|c|c|c|c|c|}
\hline & & & $\begin{array}{l}\text { berisi detail data akun } \\
\text { pengguna }\end{array}$ & \\
\hline 5 & Menu Beranda & $\begin{array}{l}\text { Memilih Menu } \\
\text { Beranda pada } \\
\text { Dashboard }\end{array}$ & $\begin{array}{c}\text { Ketika Menu Beranda } \\
\text { diklik/disentuh maka } \\
\text { aplikasi akan berjalan } \\
\text { menampilkan tampilan } \\
\text { awal }\end{array}$ & Berhasil \\
\hline 6 & Menu Tentang & $\begin{array}{l}\text { Memilih Menu } \\
\text { Tentang pada } \\
\text { Dashboard }\end{array}$ & $\begin{array}{c}\text { Ketika Menu Beranda } \\
\text { diklik/disentuh maka } \\
\text { aplikasi akan berjalan } \\
\text { menampilkan tampilan } \\
\text { informasi tentang sistem } \\
\text { layanan pengaduan }\end{array}$ & Berhasil \\
\hline 7 & Menu Kontak & $\begin{array}{l}\text { Memilih Menu Kontak } \\
\text { pada Dashboard }\end{array}$ & $\begin{array}{c}\text { Ketika Menu Beranda } \\
\text { diklik/disentuh maka } \\
\text { aplikasi akan berjalan } \\
\text { menampilkan tampilan } \\
\text { berisi informasi Kontak } \\
\text { kecamatan setempat dan } \\
\text { informasi data } \\
\text { pengembang sistem }\end{array}$ & Berhasil \\
\hline \multirow[t]{2}{*}{8} & Simpan Data & $\begin{array}{l}\text { Memilih Tombol } \\
\text { Simpan pada } \\
\text { Pengaduan }\end{array}$ & $\begin{array}{l}\text { Ketika tombol Simpan } \\
\text { diklik/disentuh maka } \\
\text { aplikasi akan berjalan } \\
\text { menampilkan tampilan } \\
\text { data aduan di Dashboard }\end{array}$ & Berhasil \\
\hline & & $\begin{array}{c}\text { Memilih Tombol } \\
\text { Simpan pada Laporan }\end{array}$ & $\begin{array}{l}\text { Ketika tombol simpan } \\
\text { diklik/disentuh maka } \\
\text { aplikasi akan berjalan } \\
\text { menampilkan perubahan } \\
\text { data verifikasi }\end{array}$ & Berhasil \\
\hline
\end{tabular}

Pada Tabel.1 terdapat data hasil pengujian yang berfungsi dengan baik. Dengan adanya sistem layanan pengaduan masyarakat kecamatan Medan Amplas ini nantinya akan membantu masyarakat melaporkan permasalahan yang terjadi di lapangan.

\section{SIMPULAN DAN SARAN}

Berdasarkan penjabaran hasil dan pembahasan dapat disimpulkan bahwa telah diterapkan produk layanan publik berbasis web yang dapat mendobrak sistem birokrasi pengaduan masyarakat agar lebih efisien. mudah dan efisien. Hasil implementasi sistem layanan pengaduan masyarakat kecamatan Medan Amplas berbasis website dapat memberikan kemudahan untuk masyarakat sekitar dan juga pejabat setempat untuk memberi pengaduan dan mengelolah data pengaduan menjadi lebih fleksibel, sederhana, dan efisien.

Penelitian yang dilakukan masih ditemukan kelemahan, oleh sebab itu saran yang dapat dibagikan adalah peningkatan sistem layanan pengaduan masyarakat kecamatan Medan Amplas berikutnya lebih disempurnakan dengan tampilan ataupun fitur pengaduan lainnya sehingga pengguna dapat lebih mudah melakukan pelaporan lainnya.

\section{DAFTAR RUJUKAN}

Firmansyah, C., \& S, C. T. (2018). SISTEM LAYANAN PENGADUAN MASYARAKAT LINGKUP DESA GUNUNGTANJUNG BERBASIS WEB DAN SMS GATEWAY DENGAN METODE ANTRIAN FIFO. JUMANTAKA, 01(01), 201-210.

Hardiansah, Safi'i, I., Suryono, S., Ciptaningrum, W., \& Primandaru, R. R. (2017). RANCANGAN APLIKASI LAYANAN PENGADUAN MASYARAKAT DENGAN METODE EXTREME PROGRAMMING ( Studi kasus : Kabupaten Ngawi ). Seminar Nasional Teknologi Informasi Dan Multimedia, 32, 7-12. 
Mahdias, H. Z., Aryadita, H., \& Wicaksono, S. A. (2019). Pengembangan Aplikasi Layanan Pengaduan Masyarakat Untuk Dinas Kependudukan Dan Pencatatan Sipil Kota Pasuruan Berbasis Android. Jurnal Pengembangan Teknologi Informasi Dan Ilmu Komputer, 3(1), 167-176.

Mursalim, S. W. (2018). ANALISIS MANAJEMEN PENGADUAN SISTEM LAYANAN ASPIRASI PENGADUAN ONLINE RAKYAT (LAPOR) DI KOTA BANDUNG. Jurnal Ilmu Administrasi ( JIA ), $X V(1), 1-17$.

Rohmatun, S., Widihastuti, I., \& Khosyi, M. (2017). Pengembangan Sistem Informasi Pengaduan Masyarakat Kabupaten Jepara Berbasis Web. Jurnal Transistor Elektro Dan Informatika (TRANSISTOR EI), 2(2), 111-123.

Sari, D. M., \& S, A. (2020). IMPLEMENTASI SISTEM PENGENALAN WISATA BAHARI BERBASIS WEBSITE KABUPATEN MAJENE. 13(2). 